\title{
Effect of smoking on MAP kinase-induced modulation of IL-8 in human alveolar macrophages
}

\author{
A. Koch*, M. Giembycz ${ }^{\#}$, R.G. Stirling ${ }^{\#}$, S. Lim", I. Adcock\#, K. Waßermann*, E. Erdmann*, K.F. Chung\#
}

Effect of smoking on MAP kinase-induced modulation of IL-8 in human alveolar macrophages. A. Koch, M. Giembycz, R. G. Stirling, S. Lim, I. Adcock, K. Waßermann, E. Erdmann, K.F. Chung. (C) ERS Journals Ltd 2004.

ABSTRACT: Inflammatory cytokine production by alveolar macrophages (AMs) is regulated by transcriptional activation and may be increased by cigarette smoking.

The smoking-induced regulation of interleukin (IL)-8 by extracellular signalregulated kinase (ERK)-1 and -2, p38 mitogen-activated protein kinase (MAPK) and the transcription factor nuclear factor- $\kappa \mathrm{B}(\mathrm{NF}-\kappa \mathrm{B})$ in lipopolysaccharide-stimulated AMs was assessed in nine smokers compared with nine healthy nonsmokers.

IL-8 production was dependent on phosphorylation of ERK-1 and -2 and p38 MAPK, as examined by PD $098059(10 \mu \mathrm{M})$, an inhibitor of the upstream activator of MAPK kinase (MKK)-1, and SB $203580(10 \mu \mathrm{M})$, an inhibitor of p38 MAPK. IL-8 release and the inhibitory effect of PD 098059 were increased in AMs from smokers. Moreover, ERK-2 messenger ribonucleic acid expression, as examined by reverse transcriptase polymerase chain reaction and phosphorylation of ERK-2 using Western blots, were increased in AMs from smokers, indicating a smoking-induced modulatory role of ERK-1 and -2. Lipopolysaccharide-induced IL-8 production was dependent on activation of NF- $\kappa \mathrm{B}$, as examined by $\mathrm{SN} 50(100 \mu \mathrm{M})$, an inhibitor of NF- $\kappa \mathrm{B}$ translocation, and the specific NF- $\kappa$ B inhibitor kinase-2 inhibitor, AS $602868(10 \mu \mathrm{M})$, with no differences in AMs from smokers and nonsmokers. SN 50 but not PD 098059 and SB 203580 blocked NF- $\kappa$ B deoxyribonucleic acid-binding, and this occurred to the same extent in AMs from smokers and nonsmokers, as examined by electromobility shift assay.

It is concluded that cigarette smoking enhances mitogen-activated protein kinase activation more than nuclear factor- $\kappa \mathrm{B}$ activation to increase lipopolysaccharideinduced interleukin-8 production in alveolar macrophages.

Eur Respir J 2004; 23: 805-812.
*Dept of Pneumology, Clinic III for Internal Medicine, University of Cologne, Cologne, Germany and ${ }^{\#}$ Thoracic Medicine, Imperial College at National Heart \& Lung Institute, London, UK.

Correspondence: A. Koch, University of Cologne, Medizinische Klinik III, Dept of Pneumology, Joseph-Stelzmann-Str. 9, 50924 Köln, Germany.

Fax: 492214787038

E-mail: andrea.koch@uni-koeln.de

Keywords: Cigarette smoking extracellular signal-regulated protein kinase human alveolar macrophages interleukin-8

nuclear factor- $\kappa \mathrm{B}$

p38 mitogen-activated protein kinase

Received: September 152003

Accepted after revision: January 262004

A. Koch was supported by the Deutsche Akademie der Naturforscher Leopoldina, Halle (BMBF-LPD 9701-12); the Deutsche Forschungsgemeinschaft, Bonn (KO-1788/31); the Lise-Meitner-Habilitations-Program of the Ministerium für Schule, Wissenschaft und Forschung des Landes Nordrhein Westfalen, Düsseldorf (44-6037.5); and the Cologne Fortune Programme, Faculty of Medicine, University of Cologne, Cologne (project 8/2003) (all in Germany).
Alveolar macrophages (AMs) play a pivotal role in the regulation of immune and inflammatory events [1, 2] and airway remodelling $[3,4]$ in chronic respiratory diseases such as asthma [5] and smoking-induced chronic obstructive pulmonary disease (COPD) [6, 7]. This includes the capacity of phagocytosis, production of inflammatory mediators such as arachidonate metabolites (e.g. leukotriene $\mathrm{B}_{4}$ and prostaglandin $\mathrm{E}_{2}$ ), nitric oxide and reactive oxygen metabolites and enzymes (elastase and metalloproteinases), and the expression of a variety of inflammatory cytokines such as interleukin (IL)-1, -2, -4, -6 and -8 , tumour necrosis factor- $\alpha$ (TNF- $\alpha$ ), interferon gamma and granulocyte-macrophage colony-stimulating factor (GM-CSF) [8]. Furthermore, AMs collaborate with lymphocytes in generating specific immune responses, including antigen presentation [9]. A variety of morphological, physiological, biochemical and enzymatic changes can be observed in AMs from cigarette smokers [10-14]. Increased numbers of AMs and neutrophils have been demonstrated in bronchoalveolar lavage (BAL) fluid (BALF) from cigarette smokers with normal lung function and smokers with COPD [6]. It has been proposed that the influx of these inflammatory cells occurs because of chemotactic factors generated in the lung in response to cigarette smoke [15].

IL-8, a member of the CXC chemokine family, activates adhesion molecule expression on endothelial cells [16] and is an important activator and chemoattractant for neutrophils [17, 18], T-cells [19] and monocytes [20]. In the dog, intratracheal instillation of IL- 8 in vivo causes the migration of neutrophils to bronchial tissue and into the luminal space [18]. Increased levels of IL- 8 have been found in induced sputum [21] and BALF from patients with smoking-related COPD associated with increased numbers of activated neutrophils and eosinophils [6] and increased colocalisation with T-lymphocytes predominantly of type-1 T-helper cell/ type- 1 cytotoxic T-cell phenotype $[22,23]$. Therefore, IL- 8 has been implicated in the initiation and maintenance of chronic airway inflammation, possibly via activation of the transcription factor nuclear factor- $\kappa \mathrm{B}(\mathrm{NF}-\kappa \mathrm{B})$ [24]. There is evidence that cigarette smoke may induce infiltration of neutrophils into the airways through $\mathrm{NF}-\kappa \mathrm{B}$ and IL- 8 gene expression in AMs [25]. These mechanisms include smoking-induced 
differences in surface expression of a subset of cell adhesion molecules (intercellular adhesion molecule-1(ICAM-1), vascular cell adhesion molecule-1(VCAM-1) and endothelial leukocyte adhesion molecule-1(ELAM-1)), associated with an increase in the binding activity of $\mathrm{NF}-\kappa \mathrm{B}$ to the consensus motif common to cell adhesion molecule genes in monocytes [25] and heightened binding of $\mathrm{NF}-\kappa \mathrm{B}$ to specific DNA sequences by dysregulated activation of protein kinase $\mathrm{C}$ in endothelial cells [25].

Transcriptional regulation of inflammatory genes, such as that encoding IL-8, in response to extracellular stimuli is achieved by a variety of different signal transduction mechanisms. One of the most extensively studied signalling pathways into the nucleus involves the mitogen-activated protein kinase (MAPK) cascade [26]. At present, there are at least three MAPK pathways, defined according to the MAPK activated: 1) the extracellular signal-regulated kinase (ERK)-1 and -2 pathway; 2) the c-Jun N-terminal kinase pathway; and 3) the p38 MAPK pathway. These are activated by different stimuli, including growth factors, cytokines, stress, pharmacological agonists and endotoxins such as lipopolysaccharide (LPS) [27]. In the present study, the potential role of these protein kinases in modulating NF- $\kappa$ B-dependent LPS-induced expression of IL-8 was examined. In addition, since cigarette smoking may modify these signalling pathways, it was also examined whether this regulatory role is different in AMs from cigarette smokers.

\section{Methods}

\section{Subjects}

Nine normal nonatopic nonsmoking volunteers (six males/ three females) and nine normal nonatopic smoking subjects (seven males/two females; cigarette consumption $\geqslant 10$ packyrs) who had no history of asthma or any respiratory disease, with normal lung function and airway responsiveness to methacholine (provocative concentration of methacholine causing a $20 \%$ fall in forced expiratory volume in one second of $>16 \mathrm{mg} \cdot \mathrm{mL}^{-1}$ ), were included in the present study (table 1). All volunteers underwent fibreoptic bronchoscopy and BAL after giving written informed consent. The study was approved by the ethics committees of the Royal Brompton Hospital (London, UK) and the University of Cologne (Cologne, Germany).

Table 1.-Characteristics of nonsmoking and smoking subjects and BALF cells

\begin{tabular}{lcc}
\hline & Nonsmokers & Smokers \\
\hline Females/males & $3 / 6$ & $2 / 7$ \\
Age yrs & $27.2 \pm 2.4$ & $28.8 \pm 2.8$ \\
FEV1 \% pred & $102.6 \pm 4.2$ & $92.9 \pm 4.6$ \\
Smoking pack-yrs & 0 & $11.2 \pm 0.3$ \\
BALF & & \\
$\quad$ Volume recovered mL & $54.5 \pm 4.7$ & $56.8 \pm 3.8$ \\
$\quad$ Inflammatory cells $10^{3}$ cells $\cdot \mathrm{mL} \mathrm{BALF}^{-1}$ & $31.8 \pm 3.6$ & $79.9 \pm 9.4$ \\
Macrophages \% & $90.0 \pm 2.3$ & $95.9 \pm 0.5$ \\
Neutrophils \% & $3.2 \pm 0.8$ & $1.7 \pm 0.2$ \\
Eosinophils \% & $0.9 \pm 0.1$ & $0.9 \pm 0.2$ \\
Lymphocytes \% & $3.9 \pm 1.7$ & $1.4 \pm 0.5$ \\
\hline
\end{tabular}

Data are presented as mean \pm SEM. FEV1: forced expiratory volume in one second.

\section{Fibreoptic bronchoscopy}

After an overnight fast, subjects were sedated with intravenous midazolam $(5-10 \mathrm{mg})$. Oxygen $\left(3 \mathrm{~L} \cdot \mathrm{min}^{-1}\right)$ was administered via nasal prongs, and oxygen saturation was monitored by digital pulse oximetry. Using local anaesthesia with lidocaine $(2 \%$ weight $(\mathrm{w}) /$ volume $(\mathrm{v}))$ to the upper airways and larynx, a fibreoptic bronchoscope (Olympus BF10; Olympus, Hamburg, Germany) was passed through the nasal passages into the trachea. The bronchoscope was wedged in the right middle lobe and four $60-\mathrm{mL}$ aliquots of prewarmed sterile $0.9 \% \mathrm{NaCl}$ were instilled. This solution was aspirated through the bronchoscope, collected in prechilled bottles and stored on ice. BALF recovery was 120-200 mL.

\section{Separation of alveolar macrophages from BALF}

The BALF was filtered through sterile gauze to exclude mucus plugs and then centrifuged for $10 \mathrm{~min}$ at $1,000 \mathrm{xg}$ at $4{ }^{\circ} \mathrm{C}$ to obtain a cell pellet. The cell pellet was washed once in $50 \mathrm{~mL} \mathrm{Ca}{ }^{2+} / \mathrm{Mg}^{2+}$-free Hank's balanced salt solution (HBSS; Sigma, Munich, Germany, and Welwyn Garden City, UK). The cells were counted using a haemocytometer (Neubauer chamber) slide and a Kimura counterstain and viability assessed by trypan blue exclusion. Cytospins were performed using $2.5 \times 10^{4}$ cells per slide, and stained with MayGrünwald Giemsa in order to obtain differential cell counts. The remaining cells were resuspended in Roswell Park Memorial Institute (RPMI; Sigma) 1640 medium supplemented with $10 \%(\mathrm{v} / \mathrm{v})$ heat-inactivated foetal calf serum (Sigma), $2 \mathrm{mM}$ L-glutamine (Sigma), $100 \mathrm{U} \cdot \mathrm{mL}^{-1}$ penicillin (Sigma) and $100 \mu \mathrm{g} \cdot \mathrm{mL}^{-1}$ streptomycin (Sigma). AMs were plated at $3 \times 10^{6}$ cells $^{\circ}$ well $^{-1}$ on to six-well plates (for electrophoretic mobility shift assay (EMSA) and Western blotting) and at $1 \times 10^{6}$ cells $\cdot$ well ${ }^{-1}$ on to 12 -well plates (for enzymelinked immunosorbent assay (ELISA)) and allowed to adhere for a minimum of $3 \mathrm{~h}$ in a humidified incubator in $95 \%$ air $/ 5 \%$ carbon dioxide (v/v) at $37^{\circ} \mathrm{C}$. Nonadherent cells were removed by washing with RPMI 1640, leaving the adherent AMs, which were $>99 \%$ pure, as assessed by staining and morphological analysis. The AMs were either harvested with a cell scraper or stimulated, cultured and then recovered. Cells were $>85 \%$ viable, as assessed by trypan blue exclusion.

\section{Cell culture}

AMs were cultured in RPMI 1640 supplemented with 10\% (v/v) heat-inactivated foetal calf serum, $2 \mathrm{mM}$ L-glutamine, $100 \mathrm{U} \cdot \mathrm{mL}^{-1}$ penicillin and $100 \mu \mathrm{g} \cdot \mathrm{mL}^{-1}$ streptomycin in a humidified atmosphere containing $5 \% \mathrm{CO}_{2}$ at $37^{\circ} \mathrm{C}$. After $12 \mathrm{~h}$, cells were stimulated in fresh RPMI 1640 supplemented as above at $1 \times 10^{6}$ cells $\cdot \mathrm{mL}^{-1}$ for ELISA for $24 \mathrm{~h}$ and with RPMI 1640 in the absence of foetal calf serum for EMSA and Western blotting for $1 \mathrm{~h}$. The ERK-1/-2 inhibitor PD 098059 (Calbiochem-NovaBiochem UK Ltd, Nottingham, UK; $10 \mu \mathrm{M}$ ), p38 MAPK inhibitor SB 203580 (CalbiochemNovaBiochem UK Ltd; $10 \mu \mathrm{M}), \mathrm{NF}-\kappa \mathrm{B}$ inhibitor SN 50 (BioMol, Hamburg, Germany; $100 \mu \mathrm{M}$ ) and NF- $\kappa$ B inhibitor (I $\kappa$ B) kinase (IKK)-2 inhibitor AS 602868 (Serono, Basel, Switzerland; 1 and $10 \mu \mathrm{M}$ ) [28] were added $30 \mathrm{~min}$ before stimulation with LPS in different concentrations and in a time-dependent manner. Drugs were dissolved in dimethyl sulphoxide (DMSO) (PD 098059 and SB 203580) or distilled water diluted to final concentrations of $<0.1 \%(\mathrm{v} / \mathrm{v})$. DMSO 
had no effect on activation of NF- $\kappa \mathrm{B}$ or cytokine transcription or expression (data not shown).

\section{Preparation of cytoplasmic and nuclear extracts}

Extracts were prepared from AMs according to the method of OSBORn et al. [29]. Cells were washed twice with ice-cold HBSS before resuspension in $10 \mathrm{mM}$ hydroxyethylpiperazine ethanesulphonic acid (HEPES; pH 7.9) containing $10 \mathrm{mM}$ $\mathrm{KCl}, 1.5 \mathrm{mM} \mathrm{MgCl}_{2}, 0.1 \% \mathrm{v} / \mathrm{v}$ Nonidet $\mathrm{P} 40,0.5 \mathrm{mM}$ phenylmethylsulphonyl fluoride (PMSF) and $1 \mathrm{mM}$ dithiothreitol (DTT) (buffer A). After a 2-min incubation on ice, nuclei were separated by centrifugation for $10 \mathrm{~min}$ at $1000 \mathrm{xg}$. Supernatants (cytoplasmic extracts) were retained. For EMSA, nuclei were resuspended in $20 \mathrm{mM}$ HEPES (pH 7.9) containing $420 \mathrm{mM} \mathrm{NaCl}, 1.5 \mathrm{mM} \mathrm{MgCl}, 0.2 \mathrm{mM}$ ethylenediamine tetra-acetic acid (EDTA), 25\% v/v glycerol, $0.5 \mathrm{mM}$ PMSF and $1 \mathrm{mM}$ DTT (buffer B) and incubated for 60 min on ice with vigorous mixing. Nuclear debris was removed by centrifugation, and supernatants (nuclear extracts) were diluted four-fold in $20 \mathrm{mM}$ HEPES ( $\mathrm{pH} 7.9$ ) containing $50 \mathrm{mM} \mathrm{KCl}, 0.2 \mathrm{mM}$ EDTA, $0.5 \mathrm{mM}$ PMSF and $1 \mathrm{mM}$ DTT (buffer C).

\section{Electrophoretic mobility shift assay}

Nuclear proteins $(5 \mu \mathrm{g})$ were used in binding reactions as originally described by OSBORN et al. [29]. Double-stranded oligonucleotides encoding the consensus target sequence of $\mathrm{NF}-\kappa \mathrm{B} \quad\left(5^{\prime}\right.$-AGTTGAGGGGACTTTCCCAGG-3') were end-labelled using $\left[\gamma_{-}{ }^{32} \mathrm{P}\right] \mathrm{ATP}$ and T4 polynucleotide kinase. Nuclear proteins from each sample were incubated with $5 \mu \mathrm{L}$ binding buffer $(20 \% \mathrm{v} / \mathrm{v}$ glycerol, $250 \mathrm{mM} \mathrm{NaCl}, 2.5 \mathrm{mM}$ EDTA, $2.5 \mathrm{mM}$ DTT, $5 \mathrm{mM} \mathrm{MgCl}_{2}$ and $0.4 \mathrm{mg} \cdot \mathrm{mL}^{-1}$ sonicated salmon sperm DNA in $50 \mathrm{mM}$ tris(hydroxymethy1)aminomethane (Tris)- $\mathrm{HCl}(\mathrm{pH} \mathrm{7.5))}$ for $20 \mathrm{~min}$ on ice. Radiolabelled oligonucleotide $(0.0175 \mathrm{pmol})$ was then added and the volume made up to $25 \mu \mathrm{L}$ with buffer $\mathrm{C}$. This was incubated for $45 \mathrm{~min}$ on ice. Specificity was determined by the prior addition of a 100-fold excess of unlabelled competitor consensus oligonucleotide. In order to confirm the identity of the components of the retarded complexes, supershift experiments were conducted, using antibodies directed against the human p50 subunit of NF- $\kappa \mathrm{B}$ (Promega, Southampton, UK) at $0.4 \mu \mathrm{g} \cdot \mathrm{mL}^{-1} 30 \mathrm{~min}$ before the addition of radiolabelled oligonucleotide. Reaction products were separated on $6 \%$ nondenaturing polyacrylamide gels in $0.25 \times 1 \mathrm{M}$ Tris-buffered ethyleneglycol tetra-acetic acid (EGTA; 0.5 M) (pH 8.0). Gels were vacuum-dried, and protein/DNA complexes were visualised by autoradiography at $-70^{\circ} \mathrm{C}$ using Kodak XOMAT film (Protein Databases Inc., New York, NY, USA). The retarded bands were quantified by laser densitometry. Band density measurements were expressed as the amount of $\mathrm{NF}-\kappa \mathrm{B}$ per microgram of protein loaded.

\section{Enzyme-linked immunosorbent assay for $I L-8$}

IL-8 was assayed using a quantitative sandwich enzyme immunoassay technique. A commercially available kit was used (DuoSet; R\&D Systems, Abingdon, UK). Briefly, $100 \mu \mathrm{L}$ mouse monoclonal antihuman IL-8 $\left(4 \mu \mathrm{g} \cdot \mathrm{mL}^{-1}\right)$ was coated on to each well of a 96-well microtitre plate (Nunc, Inc., Wiesbaden, Germany) and incubated overnight at $\sim 25^{\circ} \mathrm{C}$. After blocking for $1 \mathrm{~h}$ with phosphate-buffered saline (pH 7.4) containing $0.05 \%$ Tween $20 \AA$ and three washes, standards and samples were added and the plate incubated for $2 \mathrm{~h}$. Biotinylated goat antihuman IL-8 $\left(20 \mathrm{ng} \cdot \mathrm{mL}^{-1}\right)$ was added to the wells to sandwich immobilised IL-8. Addition of horse radish peroxidase-conjugated streptavidin (1:200 dilution of $1.25 \mathrm{mg} \cdot \mathrm{mL}^{-1}$ solution) and a stabilised chromogen and hydrogen peroxide (R\&D Systems) permitted colour development in proportion to the amount of IL-8 present, assayed by measurement of optical density using a spectrophotometer set to $450 \mathrm{~nm}$ with wavelength correction at $540 \mathrm{~nm}$ and quantified by interpolation from a standard curve. The lower limit of detection was $15.6 \mathrm{pg} \cdot \mathrm{mL}^{-1}$.

\section{Sodium dodecyl sulphate-gel electrophoresis and Western blotting}

The activation status of ERK-1 and -2 was assessed by Western immunoblot analysis using antibodies that recognise the dually phosphorylated (activated) form of the enzymes, as previously described [30]. Denatured proteins $(40 \mu \mathrm{g})$ were subsequently separated by sodium dodecyl sulphatepolyacrylamide gel electrophoresis on $10 \%$ vertical slab gels and transferred to Hybond electrochemoluminescence (ECL) membranes (Amersham Biosciences, Freiburg, Germany). The nitrocellulose was incubated for $1 \mathrm{~h}$ at $\sim 25^{\circ} \mathrm{C}$ in $25 \mathrm{mM}$ Tris-buffered saline (TBS; pH 7.6; $150 \mathrm{mM}$ $\mathrm{NaCl}$ ) containing $0.1 \%$ Tween 20 (TBS-Tween 20) and $10 \%$ $\mathrm{w} / \mathrm{v}$ nonfat milk and then for $2 \mathrm{~h}$ in TBS-Tween 20 containing $3 \%$ bovine serum albumin and primary antibodies directed against either phospho-ERK-1 and -2 (New England Biolabs, UK Ltd, Hitchin, UK) or $\beta$-actin (Santa Cruz Biotechnology/Autgen Bioclear, Calne, UK) (diluted 1:1,000). Following three 10-min washes in TBS-Tween 20, the membranes were incubated for 60 at $\sim 25^{\circ} \mathrm{C}$ min with goat antirabbit peroxidase-conjugated immunoglobulin (Ig) G (Dako, Glostrup, Denmark) diluted 1:5,000 in TBS-Tween 20 supplemented with 1\% nonfat milk for ERK-1 and -2, or for $60 \mathrm{~min}$ with rabbit antimouse peroxidase-conjugated IgG (Dako) diluted 1:4,000 in TBS-Tween 20 supplemented with $5 \%$ nonfat milk for $\beta$-actin, and subsequently visualised by ECL. The relevant bands were quantified by laser-scanning densitometry and normalised to the housekeeping protein $\beta$-actin.

Reverse transcriptase polymerase chain reaction for total ERK-2 and reduced glyceraldehyde-3-phosphate dehydrogenase $m R N A$ expression

RNA was extracted using the Qiagen kit (RNeasy Mini kit; Qiagen, Hilden, Germany) according to the manufacturer's instructions, and purity assessed spectrophotometrically. RNA was denatured for $10 \mathrm{~min}$ at $65^{\circ} \mathrm{C}$. Reverse transcription of $1 \mu \mathrm{g}$ total RNA was performed using avian myeloblastosis virus $(\mathrm{AMV})$ reverse transcriptase $(\mathrm{RT} ; 15 \mathrm{U})$; deoxyadenosine triphosphate (dATP), deoxycytidine triphosphate (dCTP), deoxyguanosine triphosphate (dGTP) and deoxythymidine triphosphate (dTTP) (each $10 \mathrm{mM}$ ); oligo-dT15 primer $(0.2 \mu \mathrm{g})$; ribonuclease inhibitor $(30 \mathrm{U})$ and $5 \mathrm{xAMV}$ buffer in a total volume of $10 \mu \mathrm{L}$ (Promega). The remaining ingredients were then added as a master mix and the samples incubated for $60 \mathrm{~min}$ at $42^{\circ} \mathrm{C}$ followed by $4 \mathrm{~min}$ at $90^{\circ} \mathrm{C}$. The complementary DNA (cDNA) was subsequently diluted to a final volume of $60 \mu \mathrm{L}$ in nuclease-free water. For PCR, $5 \mu \mathrm{L}$ cDNA solutions were used. PCR was performed using forward and reverse primers (each $0.5 \mu \mathrm{g} \cdot \mu \mathrm{L}^{-1}$ ); dATP, dGTP, dTTP and dCTP (each $10 \mathrm{mM}$ ); Taq polymerase $(0.5 \mathrm{U})$ and buffer $\mathrm{A}$ in a final volume of $20 \mu \mathrm{L}$ (Promega) for 
23 cycles for total ERK-2 mRNA and 24 cycles for reduced glyceraldehyde-3-phosphate dehydrogenase (GAPDH) mRNA, for $30 \mathrm{~s}$ at a denaturing temperature of $94^{\circ} \mathrm{C}, 30 \mathrm{~s}$ at a specific annealing temperature of $62^{\circ} \mathrm{C}$ for total ERK-2 mRNA and $60^{\circ} \mathrm{C}$ for GAPDH mRNA, and $30 \mathrm{~s}$ at an extension temperature of $72^{\circ} \mathrm{C}$. The primers for total ERK-2 mRNA were 5'-GAGCACCAGACCTACTGCCAG-3' (forward) and 5'-AATTTCTGGAGCCCTGTACCA-3' (reverse), giving a product of 416 base pairs. The primers for GAPDH mRNA were 5'-TCTAGACGGCAGGCTAGGTCCACC-3' and 5'-ACGGTACCTTAAACGGTACCCACC-3', giving a product of 598 base pairs. PCR was carried out in a Techne multiwell thermocycler (Techne, Cambridge, UK). The number of cycles was chosen after determination of the linear phase of the product amplification curve from serial sampling with increasing numbers of cycles of amplification. Products were distinguished by electrophoresis on a $2 \%$ agarose ethidium bromide-stained gel and then visualised using ultraviolet luminescence.

\section{Lipopolysaccharide}

LPS from Salmonella enteriditis (phenol extracted, gel filtered, chromatographically purified and gamma irradiated) was obtained from Sigma, Munich, Germany. The phenol extract contains up to $60 \%$ RNA and $<1 \%$ protein. Purification by gel filtration chromatography removes much of the protein present in the phenol-extracted LPS, but leaves a product that still contains $10-20 \%$ nucleic acids. Only one batch of LPS was used for all experiments in the present study.

\section{Data analysis}

Data are presented as mean \pm SEM, and were analysed by paired t-test or one-way analysis of variance. Bonferroni correction for multiple comparisons was applied. The null hypothesis was rejected when $\mathrm{p}<0.05$.

\section{Results}

\section{Lipopolysaccharide-induced expression and release of $I L-8$}

There was constitutive release of IL- 8 from unstimulated human AMs from nonsmokers and smokers (fig. 1a). IL-8 release was significantly increased $24 \mathrm{~h}$ after stimulation with LPS $\left(10 \mathrm{ng} \cdot \mathrm{mL}^{-1}\right)$. Although there was no significant difference in IL-8 release when stimulated with LPS at a concentration of $10 \mathrm{ng} \cdot \mathrm{mL}^{-1}$, more IL- 8 was obtained at the higher concentration of $1 \mu \mathrm{g} \cdot \mathrm{mL}^{-1}$ from the AMs of smokers (fig. 1a). IL-8 mRNA expression, as measured by RT-PCR, was maximal $12 \mathrm{~h}$ after LPS stimulation at $10 \mathrm{ng} \cdot \mathrm{mL}^{-1}$ without further increase at $1 \mu \mathrm{g} \cdot \mathrm{mL}^{-1}$, but there were no differences between smokers and nonsmokers (fig. 1b).

\section{Lipopolysaccharide-induced phosphorylation of ERK-1 and -2}

Under basal (control) conditions, phosphorylation of ERK-1 (ERK-1/ $\beta$-actin ratio $0.46 \pm 0.30 ; n=5)$ and ERK-2 (ERK-2/ $\beta$-actin ratio $0.47 \pm 0.15 ; n=5$ ) was detectable by Western blotting (fig. 2a and b). There was significantly greater basal phosphorylation of ERK-2 (ERK-2/ $\beta$-actin ratio $1.06 \pm 0.17 ; \mathrm{p}<0.05 ; \mathrm{n}=5)$ in AMs from smokers compared to
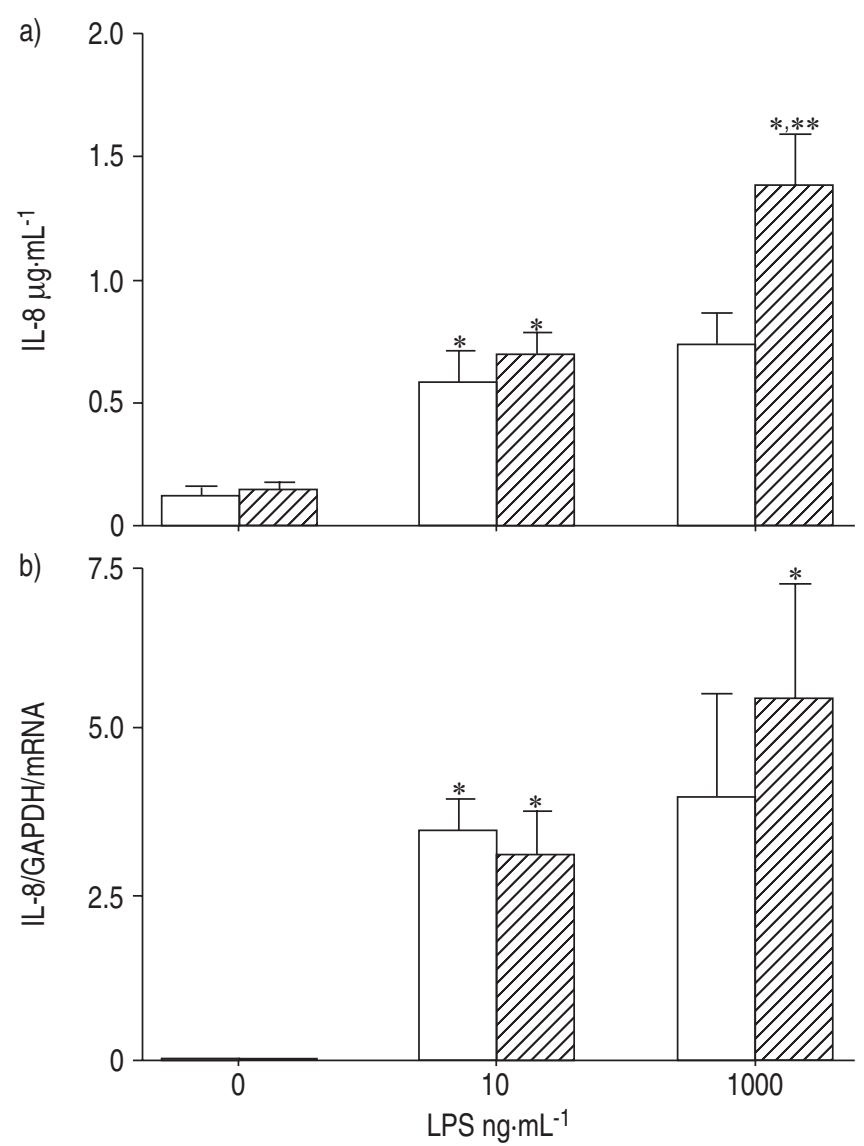

Fig. 1.-Concentration-dependence of lipopolysaccharide (LPS)induced interleukin (IL)-8 generation by adherent human alveolar macrophages in culture: a) IL- 8 generation ( $\mathrm{n}=8$ for both groups); and b) IL-8 mRNA expression as a ratio of reduced glyceraldehyde3-phosphate dehydrogenase (GAPDH) mRNA expression $(\mathrm{n}=5$ for smokers; $n=4$ for nonsmokers) in smoking (ש) and nonsmoking ( $\square$ ) subjects. Data are presented as mean \pm SEM. ${ }^{*}: \mathrm{p}<0.05$ versus controls (no LPS); ${ }^{* *}: \mathrm{p}<0.01$ versus nonsmokers.

nonsmokers. In nonsmokers, LPS $\left(10 \mathrm{ng} \cdot \mathrm{mL}^{-1}\right)$ did not cause a significant increase in phosphorylation of ERK-1 and -2 compared to control (ERK-1/ $\beta$-actin ratio $0.73 \pm 0.38$; ERK-2/ $\beta$-actin ratio $0.82 \pm 0.29 ; \mathrm{NS} ; \mathrm{n}=5)$. In contrast, in smokers, there was a significant increase in LPS-induced ERK-2 phosphorylation (ERK-2/ $\beta$-actin ratio $3.58 \pm 0.61$ in smokers; $\mathrm{p}<0.01$ versus nonsmokers; $\mathrm{n}=5$ ) (fig. $2 \mathrm{a}$ and $\mathrm{b}$ ).

\section{Lipopolysaccharide-induced total ERK-2 $m R N A$}

There was a significant increase in basal (control) total ERK-2 mRNA expression in AMs from smokers (ERK-2/ GAPDH: nonsmokers $0.37 \pm 0.02, \mathrm{n}=9$; smokers $2.52 \pm 0.81$, $\mathrm{p}<0.05, \mathrm{n}=9$ ) using RT-PCR (fig. $2 \mathrm{c}$ and e). Stimulation with LPS $\left(10 \mathrm{ng} \cdot \mathrm{mL}^{-1}\right)$ did not induce further total ERK-2 mRNA expression in smokers and nonsmokers compared with controls (ERK-2/GAPDH: nonsmokers 0.34 $\pm 0.03, \mathrm{n}=4$; smokers 1.97 $\pm 0.71, \mathrm{n}=9$ ) (fig. $2 \mathrm{~g}$ ).

Role of ERK-1 and -2 and p38 MAPK in lipopolysaccharideinduced $I L-8$ release

PD 098059, an inhibitor of the upstream activator of ERK-1 and -2, MAPK kinase (MKK)-1, inhibited LPS 

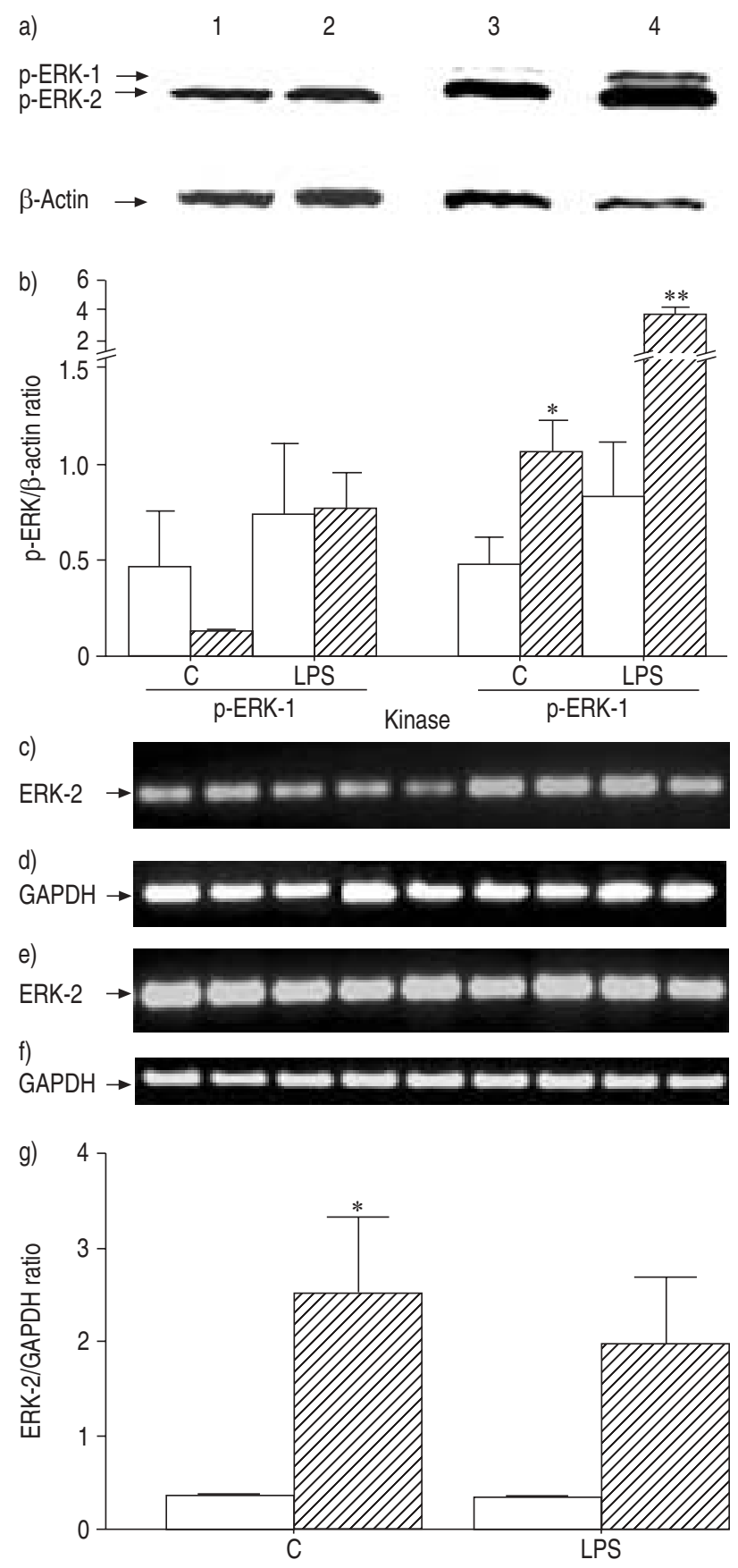

Fig. 2. - a, b) Basal (control (C)) and lipopolysaccharide (LPS; $\left.10 \mathrm{ng} \cdot \mathrm{mL}^{-1}\right)$-induced phosphorylation of extracellular signal-regulated kinase (ERK)-1 and -2 (p-ERK-1 and p-ERK-2) and $\beta$-actin expression in alveolar macrophages from smokers and nonsmokers: a) representative Western blots from nonsmokers (lanes 1 and 2) and smokers (lanes 3 and 4 ) in the presence (lanes 2 and 4) and absence (lanes 1 and 3) of LPS ( $\mathrm{n}=1$ for both groups); and b) densitometric normalisation to expression of the housekeeping protein $\beta$-actin ( $\square$ : nonsmokers; $\mathbb{Z}$ : smokers). Data are presented as mean \pm SEM ( $n=5$ for both groups). *: $\mathrm{p}<0.05$ versus nonsmokers; **: $\mathrm{p}<0.01$ versus nonsmokers for LPSinduced increase in phosphorylation. c-g) Control and LPS (10 ng $\left.\cdot \mathrm{mL}^{-1}\right)$-stimulated total ERK-2 mRNA expression: $\mathrm{c}-\mathrm{f}$ ) representative reverse transcriptase PCR gels from nonsmokers (c, d) and different smokers (e, f) showing ERK-2 (c, e) and glyceraldehyde-3phosphate dehydrogenase (d, f) (GAPDH) mRNA expression in unstimulated cultured alveolar macrophages; and g) densitometric normalisation to expression of the housekeeping protein GAPDH mRNA ( $\square$ : nonsmokers; $\mathbb{Z}$ : smokers). Data are presented as mean \pm SEM ( $\mathrm{n}=9$ for both groups). ${ }^{*}: \mathrm{p}<0.05$ versus nonsmokers. $\left(10 \mathrm{ng} \cdot \mathrm{mL}^{-1}\right)$-induced IL-8 release by $20.3 \pm 4.4 \% \quad(\mathrm{n}=6)$ (fig. 3). However, in AMs from smokers, the inhibition of IL-8 release by PD 098059 was greater $(32.0 \pm 2.8 ; \mathrm{p}<0.05$; $\mathrm{n}=7$ ) compared to nonsmokers (fig. 3). In contrast, inhibition of IL-8 release by SB 203580, an inhibitor of the $\alpha$ - and $\beta$ isoform of $\mathrm{p} 38 \mathrm{MAPK}$, was not different in smokers $(18.3 \pm 4.0 \% ; n=6)$ compared to nonsmokers $(12.6 \pm 6.8 \%$; $=$ 5 ; $\mathrm{p}=\mathrm{NS}$ ) (fig. 3).

\section{Role of nuclear factor- $\kappa B$ in lipopolysaccharide-induced} expression and generation of $I L-8$

SN 50, a cell-permeable peptide that contains the nuclear localisation sequence of the p50 subunit of $\mathrm{NF}-\kappa \mathrm{B}$ and inhibits subcellular traffic of NF- $\kappa \mathrm{B} / \mathrm{Rel}$ complexes from the cytoplasm to the nucleus, reduced LPS $\left(10 \mathrm{ng} \cdot \mathrm{mL}^{-1}\right)$-induced IL- 8 release by $71.7 \pm 23.1 \%$ in nonsmokers and $65.0 \pm 14.6 \%$ in smokers, with no significant difference between groups $(n=4)$ (fig. 3). This result was confirmed by the finding that the IKK-2-inhibitor, AS $602868(10 \mu \mathrm{M})$, reduced LPS-induced IL- 8 release by $61.3 \pm 8.1 \%$ in nonsmokers $(n=3)$ and $77.4 \pm 2.4 \%$ in smokers $(n=3)$, whereas, at $1 \mu \mathrm{M}$, AS 602868 gave only a small reduction in IL- 8 release, of $25.0 \pm 4.6 \%$ in smokers and $10.6 \pm 2.5 \%$ in nonsmokers $(n=3)$. PD 098059 and SB 203580 did not modulate the AS 602868-induced inhibition of IL-8 release in smokers and nonsmokers $(n=3)$ (data not shown).

Effects of SN 50, PD 098059 and SB 203580 on lipopolysaccharide-induced nuclear factor- $\kappa B D N A$-binding

Induction of the NF- $\kappa \mathrm{B} / \mathrm{DNA}$ complex was specific to the $\mathrm{NF}-\kappa \mathrm{B}$ consensus oligonucleotide, since an excess of unlabelled oligonucleotide prevented binding of the labelled probe. Supershift analysis was performed to identify the Rel proteins involved in these responses. In resting and LPS $\left(10 \mathrm{ng} \cdot \mathrm{mL}^{-1}\right)$-stimulated AMs, NF- $\kappa \mathrm{B} / \mathrm{DNA}$ complexes contained p50 subunits, as demonstrated by the retardation and reduction in the intensity of DNA-binding complexes caused by anti-p50 antisera, as shown recently [30]. LPS induced an

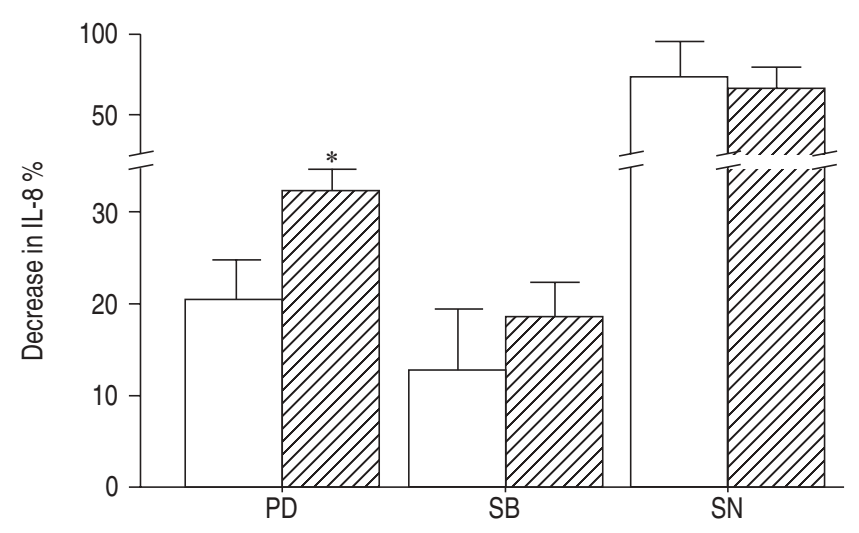

Fig. 3. - Inhibitory effect of PD 098059 (PD; $10 \mu \mathrm{M}$ ), SB 203580 (SB; $10 \mu \mathrm{M})$ and SN $50(\mathrm{SN} ; 100 \mu \mathrm{M})$ pretreatment on maximal lipopolysaccharide $\left(10 \mathrm{ng} \cdot \mathrm{mL}^{-1}\right)$-induced interleukin (IL)-8 generation in adherent alveolar macrophages from smoking ( $\mathbb{Z}$; $n=7)$ and nonsmoking ( $\square$; $n=6)$ subjects. The amount of IL-8 released into the culture supernatant after $24 \mathrm{~h}$ was measured by sandwich enzyme-linked immunosorbent assay. Data are presented as mean \pm SEM from separate experiments. ${ }^{*}: \mathrm{p}<0.05$ versus nonsmokers. 
a)
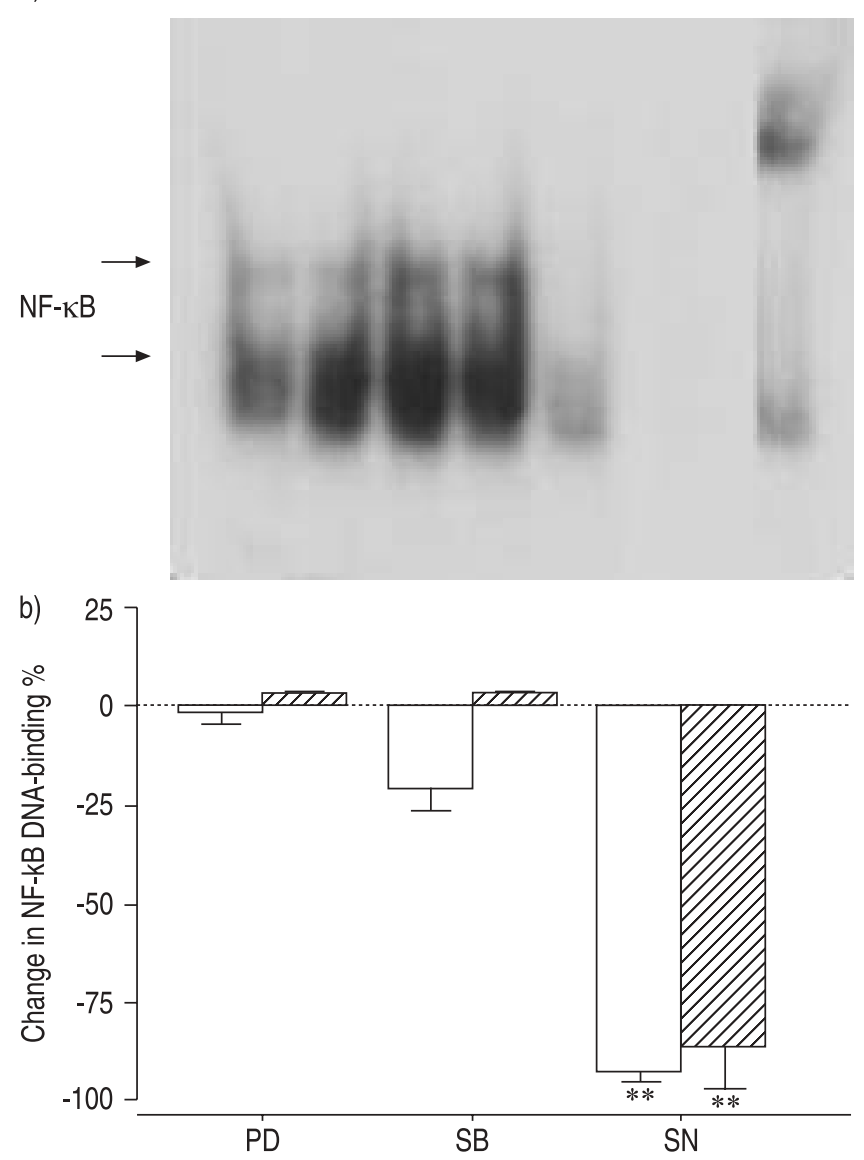

Fig. 4.-Electrophoretic mobility shift assay showing changes in maximal binding of nuclear factor $-\kappa \mathrm{B}$ (NF- $\kappa \mathrm{B}$; two bands) to the DNA of nuclear protein extracts from alveolar macrophages stimulated by lipopolysaccharide (LPS; $10 \mathrm{ng} \cdot \mathrm{mL}^{-1}$ ). a) Representative autoradiogram from a nonsmoking individual demonstrating the lack of effect of PD $098059(10 \mu \mathrm{M}$; lane 3) and SB $203580(10 \mu \mathrm{M}$; lane 4) on NF- $\kappa$ B DNA-binding (lane 1: unstimulated cells; lane 2: LPS stimulation alone). In contrast, SN $50(100 \mu \mathrm{M}$; lane 5) completely inhibited the binding. Supershift analysis was performed using antisera raised against the amino-terminus of the nuclear translocation sequence of $\mathrm{p} 50$ subunit of $\mathrm{NF}-\kappa \mathrm{B}$ (lane 7; lane 6: competition probe). b) Densitometry showing the lack of effect of PD 098059 (PD) and SB 203580 (SB) and equal inhibition of binding by SN 50 (SN) in macrophages from nonsmokers $(\square ; n=5)$ and smokers $(\mathbb{Z}$; $\mathrm{n}=5$ ). Data are presented as mean \pm SEM from separate experiments. **: $\mathrm{p}<0.01$ versus $\mathrm{LPS}$ alone.

increase in NF- $\kappa \mathrm{B}$ : DNA-binding in nonsmokers and smokers $(\mathrm{p}=\mathrm{NS} ; \mathrm{n}=5$ ), without differences in the degree of inhibition of $\mathrm{NF}-\kappa \mathrm{B}$ : DNA-binding in the presence of SN $50(91.9 \pm 3.0 \%$ in nonsmokers; $85.7 \pm 11.0 \%$ in smokers; $\mathrm{n}=5$ ). There was no inhibitory effect of NF- $\kappa \mathrm{B}$ : DNA-binding in the presence of PD 098059 and SB 203580 compared with LPS alone in smokers or nonsmokers (fig. 4).

\section{Discussion}

IL-8 was constitutively expressed in nonstimulated AMs, and there were no differences between smokers and nonsmokers. The generation of IL-8 was promoted by LPS in a concentration-dependent manner, with significantly increased release in AMs from smokers compared to nonsmokers. This finding confirms previous work showing that IL-8 release from bronchial epithelial cells from cigarette smokers is higher than that from nonsmokers [31]. Evidence is provided that activation of $\mathrm{NF}-\kappa \mathrm{B}$ and of the ERK-1/-2 and p38 MAPK pathways can induce IL-8 expression in human AMs. It is also shown that AMs from cigarette smokers produce more LPS-induced IL- 8 by modulating MAPK pathways than through $\mathrm{NF}-\kappa \mathrm{B}$ signalling pathways.

In many inflammatory cells, including monocytes [32], cytokine generation induced by LPS appears to be regulated by the transcription factor NF- $\kappa \mathrm{B}$ [33]. It has been shown previously that, in human AMs, LPS promotes timedependent activation of NF- $\kappa \mathrm{B}$; the specificity of the NF- $\kappa \mathrm{B}$ activation was confirmed by the finding that NF- $\kappa \mathrm{B} / \mathrm{DNA}$ binding complexes were supershifted by antibodies directed against the p50 subunit of NF- $\kappa \mathrm{B}$ [30]. Furthermore, the synthetic cell-permeable peptide SN 50, which has been shown to specifically antagonise the nuclear translocation of $\mathrm{NF}-\kappa \mathrm{B}$ in a diverse variety of other cell types, including mouse LE II lung endothelial cells, fibroblasts and cells of the THP-1 human monocytic cell line [34, 35], blocked the binding of NF- $\kappa \mathrm{B}$ to DNA in LPS-stimulated AMs [30]. In addition, SN 50 decreased LPS-induced IL-8 release by $\sim 70 \%$ in AMs from nonsmokers and smokers, indicating that LPSinduced IL-8 release in AMs is mainly controlled by the transcription factor $\mathrm{NF}-\kappa \mathrm{B}$ without smoking-induced differences. This was confirmed by inhibition of IL- 8 release using the IKK-2 inhibitor, AS 602868, in both groups. Interestingly MOCHIDA-NISHIMURA et al. [36] stimulated total BALF cells with $1 \mu \mathrm{g} \cdot \mathrm{mL}^{-1}$ LPS and found that cells from smokers are more sensitive to LPS-induced degradation of $\mathrm{I} \kappa \mathrm{B}-\alpha$ and activation of $\mathrm{NF}-\kappa \mathrm{B}$ compared to BALF cells from nonsmokers, indicating that LPS-induced NF- $\kappa \mathrm{B}$ activation differs depending on cell type and LPS concentration used.

A role for the MAPKs ERK-1 and -2 and p38 MAPK in LPS-induced IL-8 generation was indicated by the ability of their specific inhibitors, PD 098059 and SB 203580 [37], to modulate the release of IL-8 [38]. The high degree of specificity of PD 098059 in vitro and in vivo is indicated by its failure to inhibit 18 protein serine/threonine kinases (including two other MAPK kinase (MAPKK) homologues) in vitro and by its failure to inhibit the in vivo activation of MAPKK and MAPK homologues that participate in stress and IL-1-stimulated kinase cascades in KB and PC12 cells, and by its lack of inhibition of the activation of p70 S6 kinase by insulin or epidermal growth factor in Swiss 3T3 cells [39]. PD 098059 inhibited the activation of MAPKK2 by Raf with a much higher median inhibitory concentration (IC50) $(50 \mu \mathrm{M})$ and did not inhibit the phosphorylation of other Raf or MAPK kinase (MEK) kinase substrates, indicating that it exerts its effect by binding to the inactive form of MAPKK1 [39]. PD 098059, which is 10-20-fold selective for MKK-1 over MKK-2, was found to suppress LPS-induced TNF- $\alpha$ generation from human monocytes only at a concentration $(50 \mu \mathrm{M})$ that approaches the IC50 for the inhibition of other kinases such as MKK-2, and, in addition, significant inhibition of other kinases, including MKK-3 and MKK-6, can be expected [40]. Thus, at concentrations of PD 098059 of $>10 \mu \mathrm{M}$, the greater inhibitory action might be attributable to the inhibition of an ERK-independent MKK-2 signalling pathway.

The pyridinylimidazole compound SB 203580 is known to inhibit the p38 $\alpha$ and $\beta$ isoforms but not the $\gamma$ and $\delta$ isoforms [41]. This specificity is due largely to the presence of threonine at position 106 in $\mathrm{p} 38 \alpha$ and $-\beta$ but also involves histidine 107 and leucine 108 and exhibited significant activity against the tyrosine kinases p56lck and c-src (IC50 $5 \mu \mathrm{M}$ ) [42]. In human monocytes, SB 203580 inhibited GM-CSF generation in a

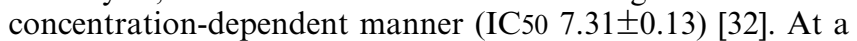
concentration of $10 \mu \mathrm{M}, \mathrm{SB} 203580$ reduced LPS-induced GM-CSF release by $\sim 80 \%$. 
There was a greater, 32\%, decrease in PD 098059-induced IL-8 release in smokers compared to only $20 \%$ in nonsmokers, and a nonsignificant, $\sim 18 \%$, decrease in SB 203580-induced IL-8 release in AMs from smokers compared with $~ 13 \%$ in AMs from nonsmokers, indicating that cigarette smoke increased MAPK-modulating effects in LPS-induced IL-8 expression.

One explanation for the differences in smoking-induced MAPK-modulated IL- 8 release could be that cigarette smoke may lead to an increase in IL-8 production through a higher level of ERK-2 phosphorylation and activation. This was supported by the finding that smoking induced an increase in basal (2.2 times) and LPS-induced (3.4 times) phosphorylation of ERK-2 in smokers compared to nonsmoking individuals.

Another explanation for post-transcriptional MAPKrelated IL-8 generation could be the fact that cigarette smoke reduces histone deacetylase (HDAC) 2 expression in AMs, as shown previously by ITO et al. [43]. The reduced HDAC2 activity correlated inversely with the induction of IL8 production in AMs from smokers [43]. Repression of HDAC2 activity may lead to enhanced histone acetylation and increased post-transcriptional IL-8 expression by modulation of DNA polymerase II [44]. Increased histone acetylation causes local unwinding of DNA, allowing increased inflammatory gene expression [43].

The fact that smoking neither changed the inhibition of p50/ $\mathrm{NF}-\kappa \mathrm{B}$ translocation by $\mathrm{SN} 50$ nor influenced the reduction in LPS-induced IL- 8 release by SN 50 or the IKK-2 inhibitor AS 602868, may indicate that smoking modulates mainly the MAPK rather than the NF- $\kappa \mathrm{B}$ pathway. The observation that NF- $\kappa$ B DNA-binding was unaffected by the inhibitor of ERK-1 and -2, PD 098059, and the inhibitor of p38 MAPK, SB 203580, in LPS-stimulated AMs and without modulating the AS 602868-induced inhibition of IL-8 release underscores the thesis that ERK-1 and -2 and p38 MAPK do not inhibit NF$\kappa \mathrm{B}$-driven transcription by blocking the translocation of $\mathrm{NF}-\kappa \mathrm{B}$ to the nucleus.

In conclusion, the present study demonstrates that lipopolysaccharide-induced interleukin-8 generation in human alveolar macrophages is mainly nuclear factor- $\kappa \mathrm{B}$-dependent, and is also modulated by the mitogen-activated protein kinase pathways, p38 mitogen-activated protein kinase and extracellular signal-regulated kinase-1 and -2 . Furthermore, cigarette-smoke induced modulation of lipopolysaccharideinduced interleukin- 8 expression predominantly occurs at the level of mitogen-activated protein kinase activation rather than through the nuclear factor- $\kappa \mathrm{B}$ pathway.

Acknowledgements. The authors would like to thank Serono Company (Basel, Switzerland) for their kind gift of the nuclear factor- $\kappa \mathrm{B}$ inhibitor kinase-2 inhibitor AS 602868.

\section{References}

1. Mazzarella G, Petillo O, Margarucci S, Calabrese C, Peluso G. Role of monocyte/macrophage population in immune response. Monadi Arch Chest Dis 1998; 53: 92-96.

2. Ward PA. Phagocytes and the lung. Ann N Y Acad Sci 1997; 832: 304-310.

3. Hamid Q. Airway remodelling in asthma. J Allergy Clin Immunol 2003; 111: 1420-1421.

4. Lim S, Roche N, Oliver BG, Mattos W, Barnes PJ, Chung FK. Balance of matrix metalloprotease- 9 and tissue inhibitor of metalloprotease-1 from alveolar macrophages in cigarette smokers. Regulation by interleukin-10. Am J Respir Crit Care Med 2000; 162: 1355-1360.

5. Chen CL, Lee CT, Liu YC, Wang JY, Lei HY, Yu CK. House dust mite Dermatophagoides farinae augments proinflammatory mediator productions and accessory function of alveolar macrophages: implications for allergic sensitization and inflammation. J Immunol 2003; 170: 528-536.

6. Pesci A, Balbi B, Majori M, et al. Inflammatory cells and mediators in bronchial lavage of patients with chronic obstructive pulmonary disease. Eur Respir J 1988; 12: 380-386.

7. Chung KF. Cytokines in chronic obstructive pulmonary disease. Eur Respir J 2001; 18: Suppl. 34, 50s-59s.

8. Barnes PJ. New concepts in chronic obstructive pulmonary disease. Annu Rev Med 2003; 54: 113-129.

9. Balbo P, Silvestri M, Rossi GA, Crimi E, Burastero SE. Differential role of CD80 and CD86 on alveolar macrophages in the presentation of allergen to $\mathrm{T}$ lymphocytes in asthma. Clin Exp Allergy 2001; 31: 625-636.

10. Pankow W, Neumann K, Ruschoff J, von Wichert P. Human alveolar macrophages: comparison of cell size, autofluorescence, and HLA-DR antigen expression in smokers and nonsmokers. Cancer Detect Prev 1995; 19: 268-273.

11. Rasp FL, Clawson CC, Hoidal JR, Repine JE. Reversible impairment of the adherence of alveolar macrophages from cigarette smokers. Am Rev Respir Dis 1978; 18: 979-986.

12. Roche N, Stirling RG, Lim S, et al. Effect of acute and chronic inflammatory stimuli on expression of proteaseactivated receptors 1 and 2 in alveolar macrophages. J Allergy Clin Immunol 2003; 111: 367-373.

13. Green GM. Mechanisms of tobacco smoke toxicity on pulmonary macrophage cells. Eur J Respir Dis Suppl 1985; 139: 82-85.

14. Harris JO, Gonzalez-Rothi RJ. Abnormal phagolysosome fusion in pulmonary alveolar macrophages of rats exposed chronically to cigarette smoke. Am Rev Respir Dis 1984; 130: 467-471.

15. Nishikawa M, Kakemizu N, Ito $\mathrm{T}$, et al. Superoxide mediates cigarette smoke-induced infiltration of neutrophils into the airways through nuclear factor $-\kappa \mathrm{B}$ activation and IL-8 mRNA expression in guinea pigs in vivo. Am J Respir Cell Mol Biol 1999; 20: 189-198.

16. Luscinskas FW, Gerszten RE, Garcia-Zepeda EA, et al. C-C and $\mathrm{C}-\mathrm{X}-\mathrm{C}$ chemokines trigger firm adhesion of monocytes to vascular endothelium under flow conditions. Ann $N Y$ Acad Sci 2000; 902: 288-293.

17. Matsukawa A, Yoshimura T, Maeda T, Ohkawara S, Takagi K, Yoshinaga M. Neutrophil accumulation and activation by homologous IL-8 in rabbits. IL-8 induced destruction of cartilage and production of IL-1 and IL-1 receptor antagonist in vivo. J Immunol 1995; 154: 5418-5425.

18. Jorens PG, Richman-Eisenstat JB, Housset BP, et al. Interleukin-8 induces neutrophil accumulation but not protease secretion in the canine trachea. Am $J$ Physiol 1992; 263: L708-L713.

19. Gesser B, Lund M, Lohse $\mathrm{N}$, et al. IL-8 induces $\mathrm{T}$ cell chemotaxis, suppresses IL-4, and up-regulates IL-8 production by CD4+ T cells. J Leukoc Biol 1996; 59: 407-411.

20. Srinivasan S, Yeh M, Danziger EC, et al. Glucose regulates monocyte adhesion through endothelial production of interleukin-8. Circ Res 2003; 92: 371-377.

21. Keatings VM, Collins PD, Scott DM. Differences in interleukin-8 and tumor necrosis factor- $\alpha$ in induced sputum from patients with chronic obstructive pulmonary disease or asthma. Am J Respir Crit Care Med 1996; 153: $530-534$.

22. Saetta M, DiStefano A, Turato G, et al. CD8+ TLymphocytes in peripheral airways of smokers with chronic obstructive pulmonary disease. Am J Respir Crit Care Med 1998; 157: 822-826.

23. D'Ambrosio D, Mariani M, Panina-Bordignon P, Sinigaglia F. Chemokines and their receptors guiding T-lymphocyte 
recruitment in lung inflammation. Am $J$ Respir Crit Care Med 2001; 164: 1266-1275.

24. Hoffmann E, Dittrich-Breiholz O, Holtmann H, Kracht M. Multiple control of interleukin-8 gene expression. J Leukoc Biol 2002; 72: 847-855.

25. Shen Y, Rattan V, Sultana C, Kalra VK. Cigarette smoke condensate-induced adhesion molecule expression and transendothelial migration of monocytes. Am J Physiol 1996; 270: H1624-H1633.

26. Chang L, Karin M. Mammalian MAP kinase signalling cascades. Nature 2001; 410: 37-40.

27. Kyriakis JM, Avruch J. Mammalian mitogen-activated protein kinase signal transduction pathways activated by stress and inflammation. Physiol Rev 2001; 81: 807-869.

28. Grimshaw CE. Identification of a potent, orally active small molecule IKK-2 inhibitor. Inflamm Res 2001; 50: Suppl. 3, S149.

29. Osborn L, Kunkel S, Nabel GJ. TNF $\alpha$ and interleukin 1 stimulate the human immunodeficiency virus enhancer by activation of the NF- $\kappa$ B. Proc Natl Acad Sci USA 1989; 86: 2336-2340.

30. Koch A, Giembycz M, Ito $\mathrm{K}$, et al. Mitogen-activated protein kinase modulation of nuclear factor- $\kappa \mathrm{B}$-induced granulocyte macrophage-colony-stimulating factor release from human alveolar macrophages. Am J Respir Cell Mol Biol 2004; 30: 342-349.

31. Mio T, Romberger DJ, Thompson AB, Robbins RA, Heires A, Renna SI. Cigarette smoke induces interleukin- 8 release from human bronchial epithelial cells. Am J Respir Crit Care Med 1997; 155: 1770-1776.

32. Meja KK, Seldon PM, Nasuhara Y, et al. p38 MAP kinase and MKK-1 co-operate in the generation of GM-CSF from LPS-stimulated human monocytes by a NF- $\kappa \mathrm{B}$-independent mechanism. Br J Pharmacol 2000; 131: 1143-1153.

33. Holtmann $\mathrm{H}$, Winzen $\mathrm{R}$, Holland $\mathrm{P}$, et al. Induction of interleukin-8 synthesis integrates effects on transcription and mRNA degradation from at least three different cytokine- or stress-activated signal transduction pathways. Mol Cell Biol 1999; 19: 6742-6753.

34. Lin YZ, Yao SY, Veach RA, Torgerson TR, Hawiger J. Inhibition of nuclear translocation of transcription factor $\mathrm{NF}-\kappa \mathrm{B}$ by a synthetic peptide containing a cell membranepermeable motif and nuclear localization sequence. $J$ Biol Chem 1995; 270: 14255-14258.
35. Xu J, Zutter MM, Santoro SA, Clark RA. A threedimensional collagen lattice activates $\mathrm{NF}-\kappa \mathrm{B}$ in human fibroblasts: role in integrin $\alpha_{2}$ gene expression and tissue remodelling. J Cell Biol 1998; 140: 709-719.

36. Mochida-Nishimura K, Surewicz K, Cross VJ. Differential activation of MAP kinase signaling pathways and nuclear factor- $\kappa \mathrm{B}$ in bronchoalveolar cells of smokers and nonsmokers. Mol Med 2001; 7: 177-185.

37. Davies SP, Reddy H, Caivano M, Cohen P. Specificity and mechanism of action of some commonly used protein kinase inhibitors. Biochem J 2000; 351: 95-105.

38. Marie C, Roman-Roman S, Rawadi G. Involvement of mitogen-activated protein kinase pathways in interleukin-8 production by human monocytes and polymorphonuclear cells stimulated with lipopolysaccharide or Mycoplasma fermentans membrane lipoproteins. Infect Immun 1999; 67: 688-693.

39. Alessi DR, Cuenda A, Cohen P, Dudley DT, Saltiel AR. PD 098059 is a specific inhibitor of the activation of mitogenactivated protein kinase kinase in vitro and in vivo. $J$ Biol Chem 1995; 270: 27489-27494.

40. Favata MF, Horiuchi KY, Manos EJ, et al. Identification of a novel inhibitor of mitogen-activated protein kinase kinase. J Biol Chem 1998; 273: 18623-18632.

41. Kumar S, McDonnell PC, Gum RJ, Hand AT, Lee JC, Young PR. Novel homologues of CSBP/p38 MAP kinase: activation, substrate specificity and sensitivity to inhibition by pyridinyl imidazoles. Biochem Biophys Res Commun 1997; 235: $533-538$

42. Gum RJ, McLaughin MM, Kumar S, Wang Z, Bower MJ, Lee JC. Acquisition of sensitivity of stress-activated protein kinases to the p38 inhibitor SB 203580, by alteration of one or more amino acids within the ATP binding pocket. $J$ Biol Chem 1998; 273: 15605-15610.

43. Ito K, Lim S, Caramori G, Chung KF, Barnes PJ, Adcock IM. Cigarette smoking reduces histone deacetylase 2 expression, enhances cytokine expression, and inhibits glucocorticoid actions in alveolar macrophages. FASEB $J$ 2001; 15: $1110-1112$

44. Zhang Y, Dufau ML. Silencing of transcription of the human luteinizing hormone receptor gene by histone deacetylase-mSin3A complex. $J$ Biol Chem 2002; 277: 33431-33438. 